\title{
Una historia sobre el cosmos del Capo: Identidades y alteridades en el Surandino
}

A History on the cosmos of Ccapo: identities and alterities in the Southern

\author{
Felipe Mario Zapata-Delgado
}

Universidad Nacional de San Agustín. Arequipa Perú.

\section{INFORMACIÓN}

\section{Historia del Artículo}

Recepción: 16/ 03/2019

Revisión: 18/05/2019

Aceptación: 22/05/2019

\section{Palabras Clave}

Fuego, caminos, entrada ccapo, alteridades, otredades.

\section{Key Words}

Fire, roads, ccapo entrance, alterities, othernesses

\section{DOI}

https://doi.org/10.35286/veritas. v20i1.219

\section{RESUMEN}

El ccapo está unida a la vida de las poblaciones altoandinas de la américa del Sur, en esta proyección graficar la diversidad cultural que adquiere esta herbácea, donde su uso e identidad está expuesto en el calor que brinda a los parroquianos en noche gélida de la altipampa, y como denuda en elemento de la fiesta patronal, Es necesario señalar que se precisan, interactúan y construyen una trama social. A diferencia de otras épocas, los protagonistas: danzantes, banda de Ccaperos, entrada de ccapo, la misa, entrada de cirios, el convite; actúan en una modernidad. Es más importante la organización; la representación y el saber mostrarse; relegando la herencia histórica del fervor que involucraba la fiesta religiosa. Entonces justamente este estudio se enmarca en indagar en la otredad, lo que no se buscó y no se vio: el origen prehispánico y colonial de esta tradición, la cual permite un conocimiento a partir de la estampas de la entrada de ccapo, la construcción de una historia cultural de Arequipa; y de otro lado la alteridad definida en una visión del ccapo como concepto epistemológico entendida como "la rebelión de los objetos" que cobran identidad y son recurrentes a la acción humana como natural consecuencia. El método, está definido por una mirada cualitativa e histórica, desde el registro etnográfico, la observación participante y entrevistas a profundidad, dentro de la mirada antropológica; y la recolección de fuentes realizado en Archivo de Cayma, Municipal, Regional y Arzobispal de Arequipa. La cual presta información vital para reconstruir y valorar la historia de Arequipa. Resultados, nos acerca hacia un percepción de un origen a partir de sistemas y estructuras como son: la cosmovisión andina, del fuego, los desastres y como estas son atendidas en la colonia mediante santos y patronos; de otro lado los caminos servirán como elementos fundamentales para fortalecer cultura, economía y sociedad, trasladando esta herbácea que servirán inicialmente para disminuir los gélidas noches de la región pero que entraran de lleno a la víspera de la fiesta patronal la cual se llena de alegría, música, banda ccaperos y la quema del ccapo, además en la actualidad la entrada ccapo se ha redefinido y se ha trasformado en un gran pasacalle en la ciudad, y en las partes altoandinas en festejos con particularidad como taripay.

\begin{abstract}
The ccapo is linked to the life of the high Andean populations of South America, in this projection graphing the cultural diversity that this herbaceous acquires, where its use and identity is exposed in the heat that it gives to the parishioners in the icy night of the altipampa, and as a denuda in element of the patron feast, It is necessary to point out that a social plot is needed, interact and build. Unlike other times, the protagonists: dancers, band of Ccaperos, entrance of ccapo, the mass, entrance of candles, the treat; They act in a modernity. The organization is more important; the representation and the knowledge to be shown; relegating the historical heritage of the fervor that involved the religious holiday. Then, precisely, this study is framed in investigating otherness, which was not sought and not seen: the pre-Hispanic and colonial origin of this tradition, which allows knowledge based on the stamps of the entrance of Ccapo, the construction of a cultural history of Arequipa, and on the other hand the otherness defined in a vision of the field as an epistemological concept understood as "the rebellion of objects" that take on identity and are recurrent to human action as a natural consequence. The method is defined by a qualitative and historical view, from the ethnographic record, the participant observation and in-depth interviews, within the anthropological view and the collection of sources made in the Archive of Cayma, Municipal, Regional and Archbishop of Arequipa. Which provides vital information to reconstruct and value the history of Arequipa. Results, brings us closer to a perception of an origin from systems and structures such as the Andean worldview of fire, disasters and how they are treated in the colony from the saints and employers, on the other hand the roads will serve as fundamental elements to strengthen culture, economy and society, moving this herbaceous or ccapo that will initially serve to diminish the icy nights of the region but that will enter fully on the eve of the employer's party which is filled with joy, music, bandcappers and the burning of the ccapo In addition, at present the ccapo entrance has been redefined and has been transformed into a large street parade in the city, and in the high Andean parts in festivities with particularity such as taripay.
\end{abstract}




\section{INTRODUCCIÓN}

Es conocido que las fiestas patronales en el Perú revisten de un valor cultural como acervo de la identidad en los feligreses, y va más allá de solo la fe ya que se torna en elementos internalizados en la propia vida de los individuos; estas fiestas tiene una etapa muy importante conocido como la víspera antes del día central, en ella se realizan diversas advocaciones de corte religioso y costumbrista; donde afloran tradiciones muy antiguas cuyo valor simbólico es entendido como el reencuentro entre el pasado y futuro es el caso de la entrada de ccapo.

Es entonces el recorrer por esta advocación para reconstruir una historia cultural del sur andino no reconocida y es en esa medida que visibilizamos desde esa perspectiva una claridad en la historia de Arequipa; El pasacalle es pletórico en ilustraciones costumbristas, productos de la tierra, danzas, potajes típicos, el lacayote, que hacen de esta pintoresca costumbre la Entrada Ccapo, manifestación del distrito de Cayma, Socabaya, Paucarpata como agradecimiento y saludo a la ciudad de Arequipa en la víspera de su fiesta cívica patronal realizada el 15 de agosto. Además, entre los andes de Bolivia, Ecuador, Perú y parte de Chile, se ha convertido en una conmemoración en los festejos patronales que se hacen en estos pueblos. Pero va más allá viene a convertirse en la síntesis viviente de todas las tradiciones y costumbres que tiene estos pueblos y Arequipa evocadas en este desfile.

La Entrada de ccapo como parte de la víspera, cobra ribetes soberbios, aproximadamente 3,000 participantes entre comparsas, danzas, estampas, vehículos alegóricos conforman este famoso pasacalle; el cual es deleite del pueblo arequipeño peruano y extranjero, que abarrotan las calles de Cayma y la ruta del ccapo hasta la plaza de Armas de Arequipa, es decir se ha convertido en una festividad costumbrista en la mentalidad del arequipeño y la región.

La Entrada de Ccapo se inicia una semana antes con la presentación de las comisiones organizadas que involucran al mismo alcalde, funcionarios, regidores, las gerencias y todo el personal en pleno de la municipalidad de Cayma.

Se realiza un "Pago a la Tierra" como era usual en épocas de antaño, antes de dar inicio a una gran festividad que conglomera a toda la población del distrito de Cayma. Un pago de esta naturaleza debe realizarse de madrugada. Trasladados en movilidades hasta el lugar denominado "Quebrada Honda" este es el inicio de la Entrada de Ccapo.

La selección de tres hojas de coca en buen estado, conocidos como "Kintu" son necesarios y es realizado por los acompañantes al maestro de ceremonia.

Mientras se prepara la "mesa" debe darse inicio a la preparación del lugar donde se depositará el pago con la participación de todos los presentes. Con "Untu" o cebo de Llama se forma el símbolo de la cruz; luego es rodeada por los Kintus de coca portadora de los buenos deseos y augurios. Todos estos elementos usados en el "pagamento" simbolizan la riqueza debe ser acompañado por dulces y caramelos, serpentinas, hiervas nativas, agua bendita, chicha, vino e incluso esencias naturales. Es necesario contar con carbón en este tipo de ceremonias propiciatorias.

El "sahumerio" del lugar con hierbas como la "cconuja" es un aspecto fundamental como parte del respeto al lugar, en el acopio de ccapo, los obreros antes de extraer el ccapo, realizan un pago simbólico a la tierra con chicha y licor llamado la Tinka.

Una vez armado los carros alegóricos para cada agrupamiento. Se ha tomado en cuenta materiales de la zona alta del distrito acopiadas días antes por el personal de la municipalidad distrital de Cayma, son utilizados para armar los carros alegóricos, además de la preparación de la chicha y el mote, en esta labor intervienen varias personas: pero la responsabilidad recae siempre en manos femeninas con experiencia, la preparación de chicha se realiza en otro lugar; requiere contar con guiñapo para su cocción y la posterior "maduración" o fermentación. Para acelerar la maduración de la chicha, estos depósitos deberán ser cubiertos. Tradicionalmente estas fermentaciones se hacían en "Chombas" pero por la gran cantidad requerida, se optó por depósitos de mayor almacenaje.

El lugar de concentración: Estadio La Tomilla, allí todos los participantes concurren los burros y caballos junto a sus dueños van llegando uno a uno. Aparecen las llamas enjaezadas. La llama que dirige el grupo tiene un atuendo especial, compuesto por un "Chullo" de color rojo, unos adornos en las orejas denominados "T'ikas", unas Campanillas de distintos tamaños e incluso una Ch'uspa como distintivo. En sus grandes recorridos, ingresarán por nuevos espacios siempre en grupo, noble camélidos de grandes distancias en la historia de Arequipa. Los pastores de llamas viajan transportando la "Yareta" usada frecuentemente para rituales como para la preparación de alimentos.

Preparar la "carga" para ser transportada por las llamas requiere destreza y conocimientos alcanzados a través de los años y de la transmisión de una a otra generación.

El "Liado" del Ccapo para ser transportado por los burros tiene que ser hecho por quienes conocen esta labor; hoy se usa alambre y otros accesorios, pero no por ello deja de ser una tarea bastante ardua. Desde el Estadio La Tomilla se "baja" con dirección a la Plaza principal de Cayma; se perifonea, se lanzan cohetes como anuncio de ingreso por las principales calles y avenidas y se porta un anuncio de saludo a la ciudad de Arequipa. Cada elemento usado en los diversos carros alegóricos es armado por el trabajo en equipo. Cada trabajador de la municipalidad tiene una responsabilidad delegada.

Las "lecheras" montadas en burro y ataviadas con vestimenta de labranza son una estampa tradicional propia de Cayma.

La "Entrada de Cirios" hace remembranza a los usos y costumbres de la época colonial. Los caballos del Valle de Chilina y su campiña se hacen presentes para dar muestras de paso elegante y de la tradición de realizar carreras de caballos los miércoles de ceniza en época de carnavales. Las danzas tradicionales y el carnaval proporcionan la alegría de festividad. En el carro alegórico de la "Picantería Tradicional" se evoca una hermosa ramada con sus "chombas" y "batanes" de piedra, con sus platos típicos preparados en "Cconcha" o Fogón; abarrotado por pobladores de todos los estratos sociales y con un fondo musical de antaño interpretado por músicos de gran trayectoria. Entonando fuertemente "Apucllay" la sátira carnavalesca se muestra en sus personajes como: "El Ccala", "El Taita Cura", "El Cholo Borracho", "La Bruja", "El Diablo" entre otros personajes principales. Los burros cargados de "Ccapo" adornados con cadenillas de rojo y blanco, sus "Cencerros" musicales 
y las infaltables banderas peruanas y de Arequipa es una imagen de las vivencias de Cayma. Con sombrero de paja tradicional, pañoleta roja al cuello, camisa blanca y pantalón jeans, este agrupamiento es el más esperado; avanzan con los sonidos diversos de los "Cencerros" guardando una distancia prudencial necesaria.

\section{Orígenes de la entrada de ccapo}

La entrada de ccapo es un referente de los usos y las formas de los arequipeños donde la constelación de costumbres, rituales y tradiciones deviene de una práctica antigua. Y el caracterizar sus orígenes, se visibiliza a través de dos componentes, $1^{\circ}$ el fuego y los desastres; $2^{\circ}$ caminos, arrieros e intercambios.

Ambos elementos son fundamentales para comprender como el hecho histórico se transforma en una representación humana todo bajo la religiosidad del pueblo.

\subsection{El fuego}

Según Motta el cronista Antonio de la Calancha halló que "Contisuyo" significaría "región del fuego", donde "fuego" provendría de "Con", una deidad de la costa peruana cuyas particularidades se visibilizan en la serpiente conocida en el Collisuyo como pichinique $(1985,11)$

Rostoworoski indica que en Chiguata -muy cerca de Cayma por camino de herradura bordeando el volcán Mistiel volcán se llama Tunupa, menciona sus "atributos una dualidad entre los de arriba y los de abajo, entre el fuego celeste y el fuego que brota en la tierra a través de un cráter humeante o abertura del mundo de abajo" (Rostoworoski 2018, 27)

La práctica ritual del holocausto de sangre (wilancha) que tuvo una amplia difusión geográfica, especialmente en el mundo aimara y estuvo vinculado a los apus y la Pachamama.

Pero el tiempo enmarca cambios y sustituciones como señala Graulich (2003), el sacrificio por sustitución cuandpo quien se inmola tiene menor estatus y reemplaza a uno perteneciente a la élite, y significa un sacrificio simbólico a través de la víctima. Los sustitutos entre los incas eran animales o productos y de ello queda un referente, en el ritual de la wilancha.

Taype ( 2005) señala varias formas de tranquilizar la deidad, y no tanto la ofrenda como se realiza en el ritual de la Pachamama sino es una obligación de hacer para aplacar la ira de la montaña:

"Pagar la deuda", pero también puede tener otros sentidos como la ablución. Los fines pueden estar expuestos por la búsqueda de a) conciliación con las deidades o antepasados, b) petición mágica de los frutos, c) petición de protección, d) forjar acciones de los elementos celestes, e) protección de las casas, f) venganza y castigo, g) ascenso y prestigio social" (pág. 2).

Entonces los Apus inicialmente fueron venerados a partir de rituales como la Capacocha y está por un mecanismo de sustitución recibe como ofrenda productos como maíz, cebada que se les ofrece. Pero la exaltación ritualista se ha ido transformando hasta quedar un proceso univoco simbiótico que es la pachamama.

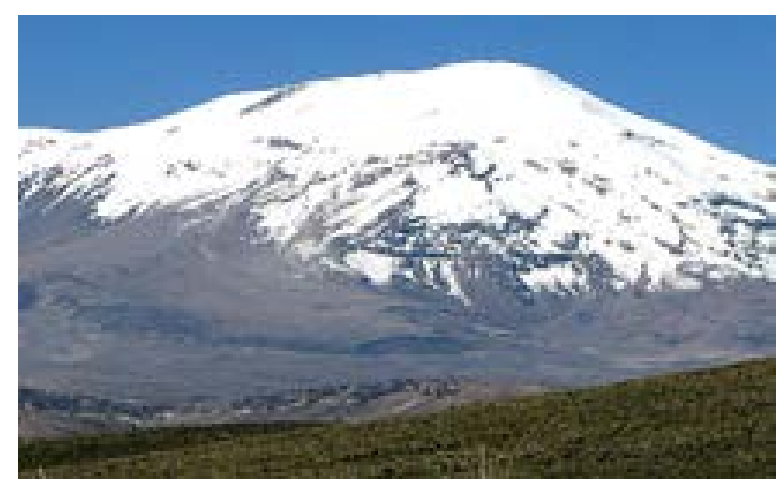

Fig.1: Ilustración, Cabrerías zona de donde se extrae el ccapo al pie del Apu Chachani

Cabrerias era el lugar ancestral del ritual de la capacocha, para desde allí desplazarse a la zona de depósito del pago al Apu Chachani y Misti, como muestra de la purificación de las comunidades de Cayma, la cual expresa dos momentos fundamentales de la cosmogonía el primero la dualidad entre el cielo Hanan Pacha y la tierra o kay pacha y un tripartición en el pago al apu donde el representante (autoridad) inicia la advocación secundado por el maestro, la ofrenda al apu es entendida como la ofrenda de su pueblo y los sectores que la conforman haciendo en el ritual se convierten en una sola unidad y es esa unidad (todos los sectores) la que se purifica en un armonía entre la naturaleza y el hombre.

\section{EI pago a la tierra, naturaleza y el hombre}

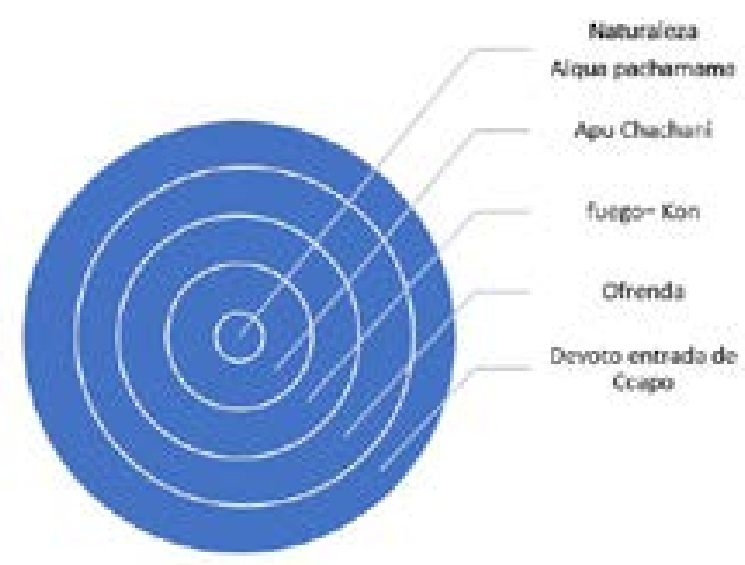

Fig. 2: El pago a la tierra, naturaleza y el hombre

Con o Kon. en el cosmos está personificado por el Sol (Inti), quien engendra luz y calor; además es el rayo, trueno o relámpago (Illapa). Entonces la especie humana evoluciono cuando pudo generar y reconocer su propio fuego.

Entonces la relación con la entrada de ccapo justamente es el fuego que se consume como efecto de la purificación y tiene una relación directa con el agua que es parte de la cosmovisión de estos asentamientos de la Chimba juntamente con la tierra; el vigor del fuego está unido como se observa con los volcanes.

A pesar de que estos rituales fueron prehispánicos trasuntan en la memoria colectiva y en el imaginario de Arequipa, es decir existen eslabones en la tradición oral que nos ha llegado a la actualidad; el fuego y el agua son la síntesis de esa cosmovisión, ya que Arequipa y Cayma en particular estuvieron permanentemente expuestas a terremotos o desgracias naturales. 
El fuego tiene la particularidad en el cosmos andino de la purificación lo cual conlleva a iluminar, engendrar, fecundar y transmutar es decir transformar el mundo cosmovitivo (funciona la autopiesis y autoregulación del sistema). Se enmarca en lo físico y lo emotivo donde las sensaciones sentidos y semntimientos3estan siempre expuesto como el enojo la cólera la alegría, el placer, violencia están. El mundo está evidenciado a partir de la sustancia o alma, Con purifica y transmuta lo negativos en lo sublime, porque es el fuego sagrado que más allá de ser iluminación y reflejado en una llama es la iluminación misma del corazón es la inherencia es importante para comprender la purificación y transmutación de lo material y lo espiritual.

\subsection{Los desastres}

Los sismos, la sequias y las epidemias fueron fenómenos que hicieron del indígena buscar una redefinición en su culto, primero en el prehispánico realizando diferentes rituales simbólicos al agua, fuego, tierra y aire; es susceptible la demostración de estos cultos, con los diversos sacrificios que se hizo a los volcanes, además del arraigo del culto al agua de la cuenca del Chili y sus tomas de los canales que irrigaban la Acequia Alta y las chacras de Cayma donde se cantaban y danzaban para que llueva; además de una necesidad de agradecer a la Pachamama donde se ofrendaban "arcos de trapo" y eran enterrados.

En la colonia tuvieron un nuevo rostro: el panteón de los dioses cristianos, es el caso de los santos y las vírgenes en el Kuntisuyu, propiamente el surandino; la cual se redefine el culto a partir de una identidad española e indígena, es por ello que en la mayoría de los casos la advocación de los santos acuñados en las diversas parroquias no prosperaron ya que a partir de una resignificación de la población se adoptan nuevos dioses, es el caso de la Candelaria, Nuestra Señora del Carmen, las Cruces icónica representación del cristo crucificado (Mota 1985)

Tanto José de Acosta como Cabello de Balboa describen los destrozos de los terremotos ocurridos en Arequipa y todo el malestar que contrajo, en el camino al volcán Misti se encuentran un sinnúmero de sacrificios incluso humanos, para apaciguar su ira. Murua menciona como Ipahuaco con el inca Pachacutec tuvieron que detener la explosión del volcán y a su vez poblar esta comarca.

En esa orden de ideas las tradiciones recogidas por Pérez Aragón (1946) "sobre las causas de la explosión del Misti y de los sacrificios de doncellas que se hicieron para conjurarla". Permiten acercarnos a la funcionalidad de lo físico erupción lava, fuego, inmanente a los temores humanos, el miedo del hombre vs. La soberbia de la naturaleza, sentimientos de misericordia confrontado con el siniestro, la cual se pued3e comprender desde internalizacion de los fenómenos naturales en la psique del humano la transforma en como poder contener esas desgracias y aparecen los sacrificios con la capacidad de detener y aplacar esta ira natural.

\subsection{El ccapo a contraluz}

En la colonia, hubo una fuerte a la practica de festividades religiosas o patronales, recurrente entre dos mundos y dos religiones disímiles, ingreso al hogar y tuvo un altar, y nació una nueva forma de fe acuñada en lo antiguo y lo moderno, entre el panteón andino y el panteón occidental. la fe en lo privado paso a la elocuencia publica evidenciado en crónicas de la época:

No existía poblado por pequeño que fuese, sin iglesia casa regular sin oratorio, cuartos sin imágenes sagradas, mes sin celebraciones, semana sin triduos y novenarios festivos, $\sin$ que se oyere una misa, por lo menos noche que no se rezare el rosario, hora que no se oyera tocar las campanas y pecho que no luciera una cruz, medalla o escapulario (Zegarra M, 1973, pág. 48).

Pero era básicamente la mentalidad que la población tenía sobre los desastres naturales que acontecieron en Arequipa; coadyuvó a una nueva forma de redefinir la identidad al interior del contexto de transformación y sincretismo de la religión católica con la andina, es en esa medida que no existía pueblo o aldehuela que no se regocijaran con las fiestas patronales e incluso de orden privado o familiar, donde la presencia del fuego proveniente del ccapo y la banda de ccaperos es recurrente:

Las fiestas patronales convocaban a toda la población en los lugares públicos y convirtiéndolo en días de masiva celebración. Se engalanaba la plaza con altares y pendones, se hacía entrada de ccapo o se quemaba castillos en la víspera...en el día de la celebración se oficiaba una gran misa y se sacaba la procesión en medio de atronadoras salvas y de desacompasada música de bandas de caperos. (Zegarra Meneses 1973, 84).

Según Motta Zamalloa (1985) en la colonia poseía sus usos y sus formas, señala que:

El esquema de culto durante el ciclo patronal en la colonia iniciaba con novenario, quinario o trinario con opcionales servicios religiosos que podían incluir procesiones exposición de Santísimo, etc. vísperas que incluían, entrada de ceras y ccapo, más tarde quema de juegos, artifíciales y castillos el día central misas cada una hora, una misa de fiesta con troya, salvas, comuniones, procesión del patrono, la que se continuaba con fanfarrias consistentes en servicios de alimentos, baile en casa del mayordomo, etc.; continuaba luego una temporada de oraciones, nueva exposición del santísimo, procesiones a solicitud de los devotos. Al cabo de ocho días de celebraba la octava del patrono, nuevamente con vísperas y actos similares a los de la fiesta central. En muchos casos los gastos de la octava corrían por cuenta de otros responsables que o fuesen los de la fiesta principal. Por lo general, el ciclo festivo concluía con la transferencia

de cargos a los responsables de organizar en el siguiente año. La renovación de cargos, sin embargo, era relativa i pues habían casos frecuentes en que las mismas personas habiendo empeñado una promesa se comprometían durante varios años de cubrir económicamente la festividad este hecho ocurría sobre todo en lugares donde no se habían consolidado las,

\footnotetext{
${ }^{1}$ Especie de objetos de vegetales cuyo tronco era flexible, el cual era recubierto con paños tejidos que tenían escenas votivas o en algunos casos eran solamente
} pedazos de telas reconocidas como de "la tierra" por ser producto del hilado de los aborígenes 
cofradías o hermandades en cualquier caso aquellas personas otras festividades menores reducían su ciclo de duración limitándose a vísperas y día central, de acuerdo al tamaño de la comunidad y: a la trascendencia de-la imagen. Aun tratándose de fiestas patronales, los pueblos de las zonas altas como Caylloma celebraban con tal fastuosidad que los pueblos de las zonas bajas no podían permitirse dado sus limitados recursos naturales (Mota 1985, 54).

La Arequipa naciente tuvo como patrona a la Virgen de la Asunción, advocada desde su fundación por Garci Manuel de Carbajal la bautizó como "Nuestra señora del Valle Hermoso de Arequipa" siendo nombrada patrona de la ciudad por el cabildo del 15 de agosto de 1562, además se instituyo en 1619 por el obispo Pedro Perea la cofradía de Nuestra señora de la asunción, su imagen se popularizo incrementándose el culto en todas la iglesias, siendo su recinto nuestra catedral donde se la venera.

Justamente retomando la redefinición de la identidad ya que en el prehispánico de Arequipa la cual era necesario aplacar la ira del Misti y Chachani; en la colonia la lectura de las catástrofes está bien referenciada y es que Arequipa sufrió de un sinnúmero de sismos debido a encontrarse cerca de la falla de San Agustín es en esa medida es que hubo una rotación de santos desde la Asunción pasando por San Sebastián, San Genaro entronizado en 1601, como se desprende del acuerdo autorizado por el Obispo del Cusco Antonio de la Raya.

Al año siguiente el mismo obispo autorizó a Mosquera levantar otro altar a San Sebastián en la ermita de San Genaro, esta medida introducía variaciones en el calendario de celebraciones por lo que Francisco de San Millán pidió al cabildo la costumbre de más de sesenta años de llevar en procesión a San Sebastián de la Iglesia Mayor a Santa Marta, adujo además que esa costumbre se hacía con toda pompa en la que intervenían danzantes, cánticos y chirimías, ....así la fiesta de San Genaro, fue rodeado con todos los ritos que estaban reservados a los patronos. Tenía vísperas con ayuno, procesiones, desde la iglesia mayor, etc.

Al cabo de un año se entró en contradicciones porque Arequipa seguía siendo asonado por los desastres.

un terrible terremoto en un volcán grande que estas tres leguas de la ciudad de Arequipa que lanzo de sí tanto fuego con tan grandes llamaradas que dicen que fue cierto haber llovido de esta ceniza en todo el reino, la cual mando hacer muchos sacrificios a sus ídolo (Murúa, 2001).

El 22 de enero de 1582 hubo un gran terremoto ya cuando los españoles estaban aposentados en esta ciudad, según Echevarría, básicamente fue un castigo divino por la falta de apego a la espiritualidad "ya habían olvidado la lectura de libros espirituales, no se conocía la oración ni se notaba la práctica de la mortificación" (1952, pág. 43)

En 1600 erupcionó el Huainaputina asolando todo el Sur: después de unos diez días continuos de «algunos temblores de poca consideración», la noche del viernes de la primera semana de la Cuaresma «arreció de manera que parecía hervir la tierra, y nadie se aseguraba ni atrevía a estar debajo de tejado». Al día siguiente, se amplificaron y menudearon los temblores. Empezaron a derrumbarse las casas, y a las cinco de la tarde oscureció el cielo, mientras que de los cerros aledaños de Socabaya «salían y se oían terribles y espantosos truenos y relámpagos que duraron hasta la oración», momento en que empezó a caer sobre la ciudad una «lluvia de cenizas» que duró hasta las once de la noche. Murúa explica que el lastimero estado de la ciudad se debía a "la ira y castigo del omnipotente Dios" (Lavalle, 2011). Existe una clara actitud frente a este desastre natural en la que el hombre no puede explicar desde su entendimiento lo que la naturaleza depara $\mathrm{y}$ tiene un aliado y ese es cristo como se menciona en esta crónica.

Según Lavalle en Arequipa, la consecuencia de semejante actitud fue un amplio movimiento penitencial que no tardó en abarcar a toda la población:

$\mathrm{Y}$ así andaban atónitos los hombres por las calles e iglesias, pidiendo confesión, y fue de suerte que la mayor parte de la gente la hizo, y los que quedaron fue por falta de confesores bastantes, y hubo personas que había más de ocho años que estaban olvidados de este sacramento, y esta noche lo pidieron a él con gran devoción [...] hubo muchos penitentes azotándose y con cruces... (Murúa, 2001)

Consideramos este dato importante ya que denotan dos posibilidades, primero que el temor al desastre es innato al ser humano y segundo que justamente esta catástrofe se cruza con la Cuaresma y el primer miércoles de ceniza, lo cual conlleva a entender dentro del imaginario colectivo como presagios de lo impune y del pecado, por lo tanto, es necesario la rehabilitación y una legitimación de la fe.

El 23 de noviembre de 1604 asoló otro terremoto, luego el 20 de mayo de 1666, el 23 de abril de 1668; el 23 de octubre de 1687, todos estos desastres llevo al colectivo a empoderarse de la fe y hacerse de dios en las parroquias del cercado y aledañas; no fue excepción Tiabaya, un ejemplo de este recogimiento fue que:

El Padre Alonso Ruiz hizo colocar en la plaza Mayor de Arequipa una cruz y comenzó una misión que recordarse a los vivientes a penitencia para aplacar la ira de Dios. En sus sermones repetía todos los días, que otro mayor castigo les había de suceder, sino aprovechaban y volvían en si con este primer aviso de dios. Lo aseguraba con tal fuerza y movimiento de su corazón, que a muchos apartó del camino de los vicios y no se le borró de la memoria de la sentencia fulminada (Echevarría, 1952, pág. 45)

Es decir, los fenómenos telúricos provocaron un recogimiento ya que al ver los desastres la población recurría a estas formas de pensamiento y religiosidad por lo letal e inexplicables actuaciones de la naturaleza.

El 13 de mayo de 1784 hubo un temblor leve, a las 5 am hubo otro que contrarió a la población. A las 7.35 se dio el gran terremoto teniendo duración de 4 y medio minutos.

El párroco de Cayma Zamácola y Jáuregui hace una prolija memoria de lo acaecido y los impactos que ocasionó este terremoto en su "Relación puntual y verídica de los estragos que causo en la muy noble y leal ciudad de Arequipa el espantoso terremoto acaecido el día 13 de mayo de 1784, por el bachiller Don Juan Domingo de Zamácola y Jáuregui, Cura de Cayma e individuo de la Real Sociedad Vascongada". (1951, pág. 320)

Conocido también como el terremoto de San Hipólito, un 13 de agosto aproximada 5 y cuarto de la tarde, con radio de alcance $1300 \mathrm{Km}$ a la redonda lo cual significa en estado desastroso; las estructuras son abatidas tanto de piedra, mampostería o madera, una descripción refiere,

..A este desgraciado pueblo agua, pan y demás artículos de consumo y de primera necesidad que habían desaparecido ocasionado por el terremoto....el que no ha respetado 
templos, monasterios, ni edificios públicos, para reducirlos a escombros"2, fue tamaña la destrucción que la Bolsa narra, "el espectáculo se presenta a nuestra vista es cada vez más aterrador, más doloroso...la orgullosa e invulnerable ciudad...reducida a escombros" ${ }^{3}$

Existe hoy día en la memoria popular de la población siempre se libró y salvo de diversas calamidades que azotó a Arequipa. La naturaleza cumple con un papel: el de hacer que el bienhechor se agigante en la mentalidad colectiva.

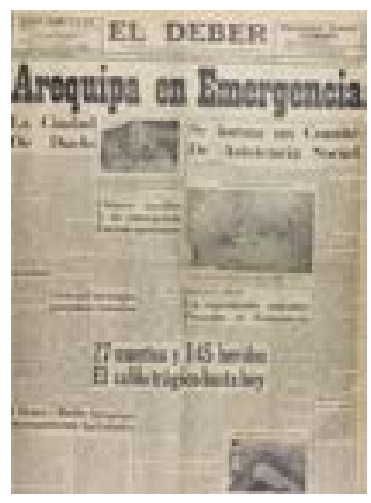

Fig. 3: Ilustración, El deber anuncia el desastre

El 13 de enero de 1960, las ciudades de Chuquibamba, Caraveli y Cotahuasi quedaron en escombros. En la ciudad de Arequipa muchas de las antiguas construcciones de sillar ubicadas en el Centro Histórico (dañadas en el terremoto de 1958) se destruyeron. Tiabaya, Tingo, Huaranguillo, Sachaca, Alata, Arancota, Pampa de Camarones, Chullo y Hunter exhibían un $90 \%$ de sus viviendas en ruinas.

En el 2001 un 23 de junio no se hizo espera un gran terremoto que destruyó el centro histórico de Arequipa y diversas zonas quedaron devastadas, además del Tsunami cuyos destrozos más álgidos hizo desaparecer parte de Camaná con olas de hasta 8 metros.

Es decir la actualidad es evidencia de lo que vivió la región y como era necesario el recogimiento , la misericordia, la compasión que se internaliza en esta comunidad, llevándolo ribetes sagrados y entendido como castigo divino; están muy unidos elementos de la naturaleza con la conmiseración humana, es el recuento del viaje de los seres humanos en su historia en el decurso universal.

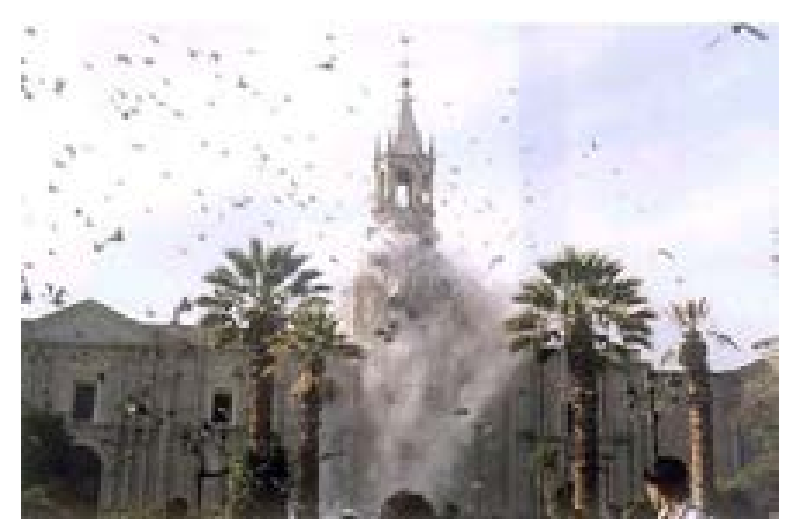

Fig. 4: Ilustración, La Catedral de Arequipa y el terremoto del 2001

\subsection{Caminos, arrieros e intercambios}

\subsubsection{Los Llameros y trajinantes}

Existe un avance vertiginoso en la que lo que ayer era importante hoy día simplemente no existe, y esto se da por ejemplo en los oficios y uno de ellos secular y fundamental en la vida de los hombres, es el de los pastores de puna cuya movilidad y dinamicidad va cambiando al ser arrinconados a las regiones más altas donde de los llameros hoy día se circunscriben a espacios más reducidos

Para Medinacelli presentan dos características:

a) Es una colectividad sumamente móvil que, en algún momento, fue parte de una sociedad seminómada. b) A pesar de que se los ve, y ha visto, como uno de los sectores profundamente tradicionales, por su carácter móvil, se constituyen en mediadores culturales por excelencia.

Además Ximena Medinacelli (2010) señala que estos hombres percibieron su existir a mediante movimientos trashumantes, uniendo la sierra y la costa, las punas con zonas templadas o valles interandinos y valles de yunga lo cual coadyuva ante zonas no habitadas, lugares inhóspitos, donde se cargaba símbolos que llevaban los arrieros y trajinantes con llamas que cruzaban de zonas esteparias, salares, lugares de producción de camélidos para el charqui y de allí hacia la zona más bondadosa llegando a la costa cuyos recursos eran apetecibles, formándose una sociedad de pastores cuya identidad fue única y fundamental para el movimiento de la economía, sociedad y cultura en todo ese espacio y los puntos ruteros por el cual se desplazaban e allí su importancia.

Lautaro Núñez (2017) es eficaz en este sentido al señalar que la arqueología del sedentarismo y urbanismo plagó de conjeturas erróneas sobre la costa, viéndola esta con una dinámica centralizada y cuyo eficacia radicaba más en la agricultura a diferencia de la sierra que por ser definida por pastores, tuvo una tendencia móvil permanente, Lautaro propone que esta movilidad fue integral tanto en la sierra como en la costa, precisando que la movilidad es la base de la economía caravanera, siendo las feria o Qhatus los ejes de estas economías. La alta movilidad se debe básicamente en una necesidad económica señalada por Khazanov (1984) como el "Mundo de fuera", que buscan dinamizar, articular y potenciar pueblos sedentarios y urbanos.

En la colonia el arrieraje cobra una vital importancia ya que el transporte jugó un papel integrador a partir de los centros mineros y sus circuitos, la arriería fue básico en el transporte de ganado y bienes, el arriero se desenvolvió como trabajador en el traslado de mercancías o animales (fletes) o independientemente abasteciendo mercados con recursos propios adquiridos por su cuenta (Sica, 2010). Además Gabriela Sica puntualiza:

La arriería suele utilizarse como sinónimo de tropería y del transporte de animales en pie para su venta; sin embargo se trataba de dos actividades que contaban con mano de obra especializada, oficios específicos con diferentes aprendizajes y categorías al interior de cada uno de ellos. La conducción de ganado en pie la realizaban los mismos productores, su capataz u hombre de confianza, quienes llevaban las tropas hasta las zonas de engorde, ferias de ganado o sitios de faenamiento; para esta tarea contaban con mano de obra

${ }^{2}$ Arch. Municipal libro 4 cabildo, fol 80, 17 de agosto 1868

${ }^{3}$ Diario la Bolsa Arequipa 22 de agosto de 1868 
especializada, sobre todo con baqueanos, conocedores de los caminos, sendas, pasturas y aguadas a las que se podía acceder en cada jornada, y también personal de amanse junto con toda una gama de peones y aprendices en el arreo. Por otra parte, la conducción de vacas, mulas y caballos, necesitaban tierras más fértiles recurriendo a los caminos más cortos para atravesar las zonas desérticas o de alta montaña A diferencia de ello, el arreo de mulas cargadas para fletes podía realizarse por senderos con pocas pasturas y aguadas por donde se accedía más rápidamente a los centros mineros del Alto Perú (2010, pág. 25)

Es necesario recalcar que la economía del arrieraje tenía como protagonista principal al indígena y era él quien realizaba los contratos de traslado, además este personaje irrumpe en la red económica porque conoce los caminos, abrevaderos, alimentos que se encuentran desperdigados en el Ande, además las llamas están mejor adaptadas a las condiciones climáticas alto andinos y está en condiciones inmejorables para su crianza y desarrollo:

A diferencia de otro ganado europeo, las llamas estaban mejor adaptadas a los ambientes altos y áridos de la Puna, consumían forraje natural y no precisaban un elevado número de hombres para guiarlas. Esto permitió una fuerte presencia de indígenas en la actividad, característica que se mantendrá a lo largo de la etapa colonial, ya que el manejo de una tropa para caravanéo exigía una tecnología adecuada para su crianza y domesticación como animales de cargas, sumado al conocimiento de los caminos, aguadas, pasos, pascanas y tambos. De esta manera, los indígenas adquirieron un papel clave en la temprana circulación mercantil a través del uso de los rebaños de camélidos cuya propiedad no habían perdido con la conquista" (Sica, 2010, pág. 32)

Es necesario notar que en los inicios coloniales tanto la llama como los animales europeos coexistían en la economía del arrieraje, existen muchos documentos donde se indica que los indios realizaban fletes trasladando productos de una zona a otro con estos dos tipos de animales, las llamas pertenecían indígena y las mulas al encomendero, eso no significa que los indígenas no adquirieran mulas.

Para Flores, Contreras y otros, este tipo de economía del llamero es un «agente intercomunicante». Los pastores se constituyen en dinamizadores de las relaciones sociales e intercambio «tradicional» con el mercado. Para West significa un replanteamiento de la articulación de la economía llamera a mercados prehispánicos y coloniales. Es evidente que la existencia de mercados precoloniales está definido por el control vertical y la maximización de los pisos ecológicos, siendo tres los productos fundamentales de este comercio: Sal, Coca y Ganado. Es decir la economía llamera y alpaquera está definida por la movilidad e intercambios ${ }^{4}$.
Según Carmen Escalante y Ricardo Valderrama (1983)

Los llameros que tuvieron tanta importancia hasta los años cincuenta y sesenta en que son desplazados por el transporte motorizado, su amplia red de intercambios económicos en la región se reduce a los límites departamentales de Huancavelica. Los llameros actuales realizan sus viajes a las punas y quebradas de las provincias de Huancavelica, para satisfacer las necesidades de sus unidades domésticas, así como para abastecer de ganado los canales de las ciudades de Huancavelica y Huancayo (pág. 86).

Lo interesante de este periplo es que el arrieraje en su trajín en el sur peruano edifica una red comercial de productos básicos para su subsistencia a partir del trueque, esta red comercial muestra indicadores particulares en la época prehispánica como se ha visto, que se fija de acuerdo a zonas de producción generalmente valles. Luego con los incas consolidan una red basada en vías troncales o Capac Ñam que salen desde el Cusco e integran el Kuntisuyu (Arequipa).

\subsubsection{Arrieros y comercio}

En la colonia la red comercial está aperturada por nuevos centros económicos articulados por las minas de Potosí, es aquí donde se dibuja el personaje de nuestra historia es decir el indígena arriero, inicialmente con llamas y después mulas convirtiéndose un viajero permanente en el Surandino y por ende la rutas que unen Arequipa con la costa y la sierra, estas últimas tienen como caminos fundamentales aquellos que salían de Cayma.

Pero ¿cómo se dio el sistema de arrieraje en Arequipa?, podemos tomarla en cuenta por la propiedad de los animales: los encomenderos y comerciantes vinculados a las elites locales y regionales, contaron con más de 250 animales, y los mestizos e indígenas que tuvieron acémilas menores, cuya función era trasladar la cosecha e insumos vinculados con la agricultura además de trasladar leña y carbón (Benavente, 2010), estos eran propietarios de llamas en las partes altas de Arequipa; debemos notar que existió una comercialización fluida entre los punarunas y llactarunas o chacareru en las zonas altoandinas y los valles de Arequipa, de cuyos intercambios se ha ocupado Tomoeda (1977).

El arrieraje cubrió los circuitos de comercialización en la colonia y hasta la década del 50 del siglo XX. Algunas de esas rutas son señaladas por Benavente así:

La primera: partió de la Pampa de Miraflores a Chiguata, siguiendo por Chucuito, pasando por la Paz, hasta llegar a Potosí y Chuquisaca en el Alto Perú. La Segunda: salió de Yanahuara, seguía por Cayma, Cañaguas, pasando a Puno y llegando al Cuzco; La Tercera: para la región del Collesuyo, partió de la Ranchería y seguía por Characato, Pocsi, Puquina

${ }^{4}$ Es aleccionador el estudio de Medinacelli que al respecto señala algunas características : 1) las implicaciones de la coexistencia del trueque con la compra/venta; 2) la relación entre pastores y agricultores; 3 ) la articulación de los pastores con otro tipo de actividades (minería, venta de mano de obra, comercio...); 4) la planificación del uso del tiempo en la economía pastoril; 5) la importancia de los productos que intercambian (más importantes que los «caseros» o compradores); 6) los circuitos de intercambio; 7) la función de los «caseros» y el manejo estratégico de instituciones sociales»;8) las caravanas y las identidades de género; 9) los rituales de viaje; 10) el papel de las ferias; 11) las transformaciones históricas de las formas y espacios de intercambio; 12) el rol de los llameros como mediadores culturales; y 13) la determinación en cada momento histórico de cuál constituye «el mundo de afuera» y quiénes fueron los pastores. 
y Omate. La cuarta ruta: partió de Antiquilla a Challapampa, Uchumayo, Vitor e Islay. En esta ruta agregamos aquella que articularon los pueblos de la región sur hasta Tarapacá y los del norte de Arequipa."

Entonces, nuestros "personajes históricos" que después se refundirán en la entrada de Ccapo son: mulas, llamas, el arriero, el trajín y el Ccapo, reconocidos en la historia de Arequipa y de Cayma a partir de su papel en el desarrollo comercial del sur andino, que ahora la denominamos representación ${ }^{5}$ estampa, alegoría o víspera ritual de la fiesta patronal, es decir la entrada de Ccapo es producto de una apropiación de aspectos históricos determinados en el tiempo, que ha sido transformado por las generaciones y su cultura, hasta convertirse en un elemento fundamental de las fiestas patronales. Creemos que estas estructuras se renuevan y se redefinen, así la representación da un sentido cultural y un apropiamiento del fenómeno cuya cristalización está en: el conocer, el nombrar y el usar.

\subsubsection{Los Caminos de Cayma}

El transporte en el prehispánico estaba definido por la necesidad de uso de acémilas sobre todo llamas, de allí que los caminos tenían un uso específico para estos animales y los hombres, donde los tambos jugaban un papel importante.

Hislop (2010) (citado por Mariela Sica) señala:

La dominación incaica, produjo un gran cambio en la circulación de bienes y personas al desarrollar un sistema vial centralizado que unía el Cuzco con las regiones más distantes del Imperio. Si bien se mantuvieron muchos de los patrones de circulación prehispánicos, la centralización y el planeamiento estatal introdujo nuevas complejidades a la antigua circulación. La red vial o Capac Ñan, con frecuencia establecida sobre rutas y corredores preincaicos, estaba compuesto de vías principales y secundarias. Desde Cuzco, partían los cuatros caminos principales hacia los cuatro suyus del Imperio, y de ellos se derivaban una impresionante red de caminos, con collcas o depósitos y un sistema de postas o tambos que permitían a los viajeros y caravanas proveerse de forraje, alimento, agua y un sitio de descanso al final de una jornada de viaje (pág. 25)

Cieza de León (2005) (Citado por María Hocquenhagen), anota:

Una de las cosas de que yo más me admiré, contemplando y notando las cosas deste reino, fue pensar cómo y de qué manera se pudieron hacer caminos tan grandes y soberbios como por él vemos y qué fuerzas de hombres bastaron a los hacer y con qué herramientas y instrumentos pudieron allanar los montes y quebrantar las peñas, para hacerlos tan anchos y buenos como están porque me parece que si el Emperador quisiese mandar hacer otro camino real, como el que va de Quito al Cusco o sale del Cusco para ir a Chile, ciertamente creo que todo su poder para ello no fuese poderoso ni fuerzas de hombres lo pudiesen hazer si no fuese con la orden tan grande que para ello los Incas mandaron que hobiese. (hocqengahem, 2016, pág. 10)

En la colonia, la corona se preocupó en reestablecer los caminos prehispánicos y en algunos casos el de realizar tramos que permitiesen la explotación de la minería, es decir la funcionalidad de estos caminos radica en la necesidad de articular al nuevo sistema económico que era propiamente basado en la minería, como lo señala Glave ( 1989) (en Hocqengahem)

Con el surgimiento de nuevas formas de transporte como las mulas en vez de las llamas o el surgimiento de los arrieros mestizos en reemplazo de los indios. ¿Qué es lo que se mantuvo de este sistema? Los caminos y los puentes indígenas, el trabajo gratuito para el mantenimiento del sistema, los tambos, la servidumbre y dominación colonial, condiciones de la circulación pero en un mercado dominado (pág. 10)

En tiempos republicanos este proceso se modifica ya no es la articulación minera sino la explotación de las lanas en las zonas altoandinas las cuales son traídas a Arequipa y desde aquí se exportan a mercados europeos ${ }^{6}$, como nos hemos referido ${ }^{7}$ indica que era necesario el mantenimiento del sistema de caminos, además de ampliar tramos, todo esto hecho con la mano de obra indígena.

Verdaderamente la importancia de Cayma en la Historia de Arequipa, se refiere a que era la zona por donde se ingresaba a la ciudad, mediante el camino real y los diversos caminos de herradura que unían Cusco, Puno y Caylloma. Veamos los caminos que utilizaron en sus desplazamientos hacia el valle del Chili; los Chumbivilcas, cuyo hábitat era la margen derecha del río Santo Tomas, se desplazaron por el camino que ha servido de base a la actual carretera que comunica a la provincia de Santo Tomás con la ciudad de Arequipa; los Yanahuaras que se ubicaban en la margen izquierda del citado río se desplazaron por el camino que usaron los Chumbivilcas. Los Collaguas, bajaron por el sector de Callalli, dejaron vestigios en la Pulpera, la Ventana del Colca, Tocrapampa, Llapa-yanahuara, Pampa Cañahuas,

\footnotetext{
${ }^{5}$ Toda sociedad, es diferenciada por la percepción de su propia cultura y va a esgrimir representaciones a partir de un proceso de cognición y sobre todo un proceso de legitimación de la misma, para ello es necesario anotar que la percepción es según Marcela Romo (1998): “En términos simples, la percepción social se define como los efectos de factores sociales y culturales sobre la forma en que se estructura nuestra cognición del entorno psíquico y social. La percepción no depende únicamente de los estímulos presentes y de las capacidades de los órganos sensoriales. Ella depende igualmente de las experiencias pasadas del individuo y de su comportamiento actual que está mediado por valores, necesidades, recuerdos, humor (espíritu), de circunstancias sociales y aspiraciones." Entonces la percepción en entorno cultural no es comprendida como "la verdad" sino por lo que se cree que es verdadero, y justamente estas creencias costumbres y "buen entender", son las que modelan el comportamiento. El ser humano a lo largo de su vida adquiere elementos de su entorno que se prefijan y le condicen a tener una idea y un concepto deformado de su realidad, filtrado por un tamiz que se llama "su cultura". Y la representación social, podemos entenderla como: “... una forma de conocimiento elaborada y socialmente compartida, constituida a partir de la experiencia, las informaciones, saberes, modelos de pensamiento recibidos y transmitidos por la tradición, la educación y la comunicación social. Su objetivo es práctico. La representación apunta al dominio del entorno, a la comprensión de los hechos y las ideas que dominan el entorno. La representación social participa en la construcción de una realidad común a un conjunto social". Entonces es necesario añadir que tanto la percepción como la representación definen dos aspectos el sicológico y el social del mismo mundo, y está adquirido en un tiempo histórico en la pugna permanente de su práctica y de su aceptación. UNESCO, 1977: 1, En: MARCELA ROMO MARTY Pastores del Sur Andino. Percepción y representación del ambiente, Estudios Atacameños $\mathrm{N}^{\circ} 16-1998$, p. 210

${ }^{6}$ Manuel Burga y Wilson Reátegui, además de las opiniones del Nelson Manrique

${ }^{7}$ Véase: Burga y Reategui, Lanas y Capital mercantil
} 
Pisac, Tocra, Cabrerías ${ }^{8}$, Piedra de Piccho y Arequipa ${ }^{9}$ Reconociéndose hasta ahora, como el camino de llameros, la cual llegaba a TocraWasi, donde se realizaba el descanso y algunos intercambios, y se continuaba. Este aspecto es fundamental para desentrañar algunos hechos históricos como la percepción del sistema de sustento que tenían estos hombres la que estaba basado en una economía interzonal, es decir se dio un intercambio vertical entre los diversos grupos que hubieron tanto en Cayma, Yanahuara, Arequipa y las zonas altas ${ }^{10}$, es necesario entrever que hasta hace algunas décadas la población de Charcani, La Tomilla, Carmen Alto y la Acequia Alta, comercializaban de manera permanente con grupos humanos que venían de Tambo Cañahuas (RNSAB), Huayllacucho y Chilligua, estos comerciantes traían carne salpresada y fresca, además de granos, sogas e intercambiaban con frutas, y productos de panllevar; además estaban Chiguata, Mosopuquio, Cayma y otras zonas en las faldas del Chachani y el Misti, es menester destacar que estos productos eran trocados o vendidos dentro de una compleja red económica que finalmente terminaba en el mercado San Camilo o continuaban hacia Vítor, Siguas y la costa, como también Puquina, Omate en Moquegua.

Es decir, los caminos tenían a Cayma como el trayecto indispensable entre la zona altoandina y Arequipa. Como se puede apreciar en la imagen la cual nos muestra parte de la Reserva Nacional Salinas Aguada Blanca, como un sector de intercambio comercial y parte de una red compuesta por Cabrerías donde podemos ver los antiguos caminos collaguas, que aún se conservan; tienen $5 \mathrm{~m}$ de ancho, aún están bordeados por piedras. Ubicado en la cara sur del Chachani que se unen a la red vial del Capac Ñan, es la unión de dos senderos que vienen del Colca y justo en el centro se ubica el Chachani; en el lado derecho nos encontramos con el camino que nos lleva hacia la zona de Tuti (Caylloma) y por el lado izquierdo vemos el camino que nos conduce hasta Orqueta que nos lleva después hacia Pampa de Arrieros y nos conduce hacia el Colca por la zona de Yanque y el punto de referencia era una gran montaña conocida como Nocarani

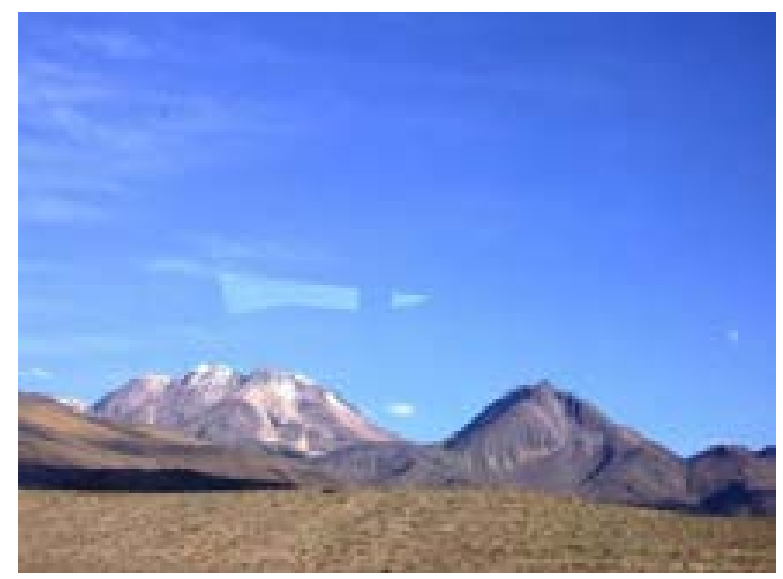

Fig. 5: Camino de herradura en el Chachani

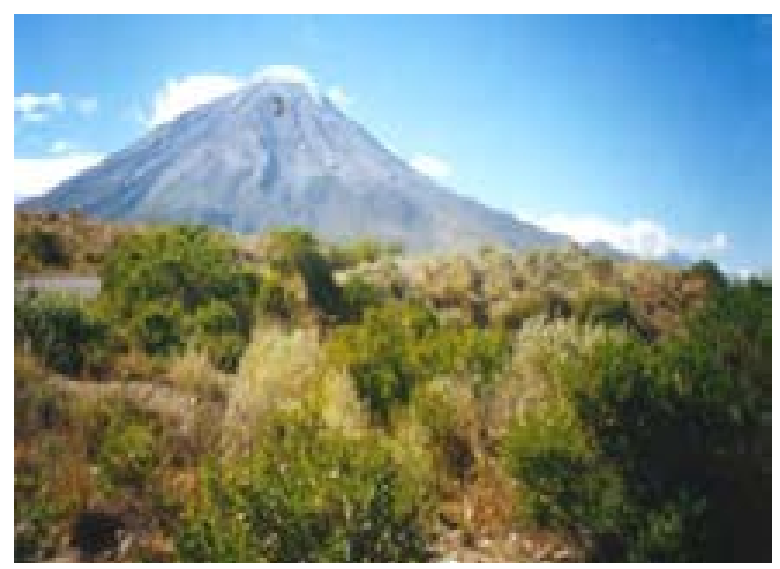

Fig. 6: Vista del Apu Misti desde Cañahuas

Podemos concluir que los arrieros desde tiempos prehispánicos enlazaron e intercambiaron productos de Cayma con el las Zonas Altoandinas y la Costa, por caminos como se observa en este paramo del Chachani generando costumbres y representaciones en el imaginario que posteriormente se ha de llamar entrada de Ccapo como una estampa representativa de estos periplos, prehispanicos, coloniales y republicanos, en pos del desarrollo de las comunidades y pueblos, es decir esta estampa costumbrista es asumida en las fiestas religiosas como una representacion por sustitucion de una dinamica comercial y elementos religiosos andinos y catolicos, cuyos actores reales fueron las carvanas de arrieros.

\section{Carmen Alto, despensa del intercambio de productos con zonas alta}

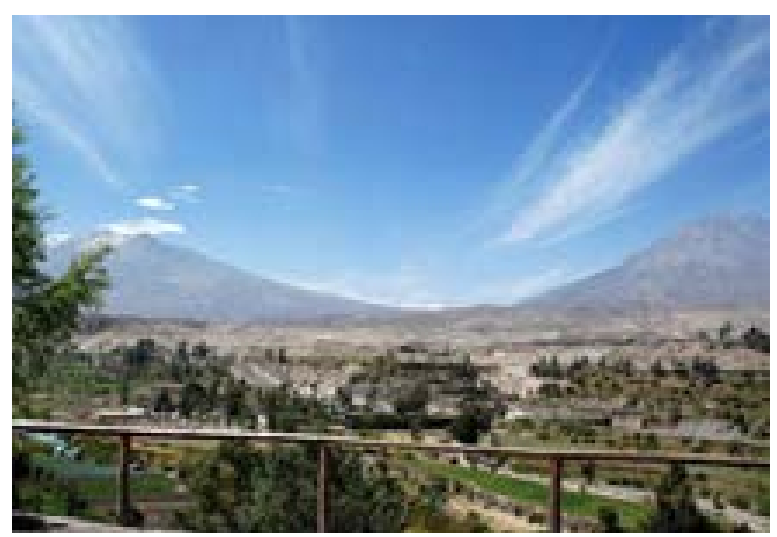

Fig. 7: Mirador de Chilina

${ }^{8}$ Se la denominó así porque en esta zona se pastaban chivos, cabras y ovejas de la Tomilla, Carmen Alto, Acequia Alta y Charcani, dato recogido de Zacarías Zeballos Colque

${ }^{9}$ Galdos Rodríguez, Kuntisuyu

${ }^{10}$ tal como lo expuso Murra y en la actualidad Mayer, 


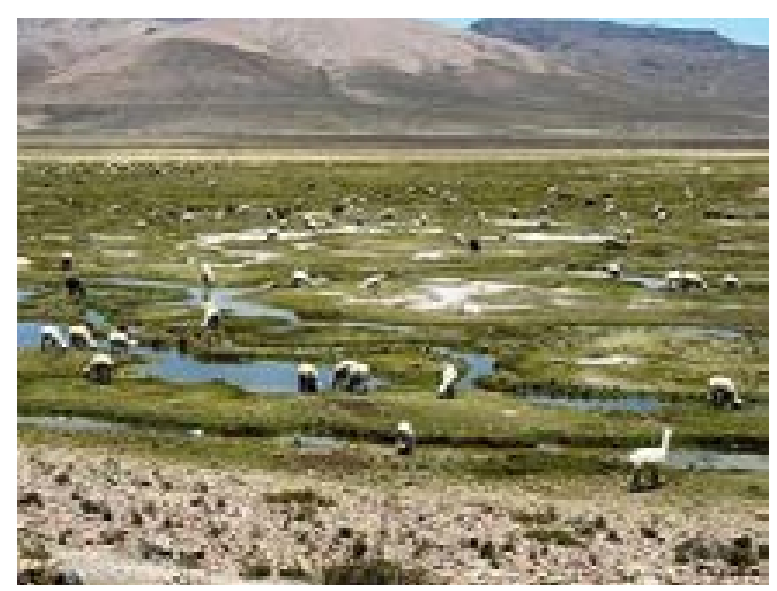

Fig. 8: Reserva Nacional Salinas Aguada Blanca

\section{Métodos}

\subsection{Cualitativa}

Para McLeod y Thomson (2009) y Patton (2002) buscan lograr ideas, interpretar, comprender y ese vasto conocimiento va desde la historia, geografía, educación, economía, roles funciones, parentesco, población demografía migraciones y movimientos

\subsection{Histórico}

El método histórico según Simiand (2003) es el proceso cuyo método es indirecto ya que el objeto de investigación no es observable más por medio de todo tipo de fuentes por lo tanto es experimental indirecto, el cual es indirecto en el espacio y en el tiempo ciudades que no existen que estuvieron en un espacio determinado, pero que existieron; igualmente solo en un tiempo existieron y ya no existen mas, entonces no se concibe la reconstrucción de esos mundo más que de manera indirecta. Estos conocimientos son producidos a partir de un uso muy depurado de fuentes y su análisis que detallamos.

Este definido de acuerdo a Ciro Flamarión Santana Cardoso y Perez Brignoli quienes analizan que la investigación histórica al ser un objeto indirecto se puede construir a partir de fuentes; su proceso contempla:

La Heurística,

Hermenéutica

Critica

Síntesis

Exposición
- Fuente documental: Archivo Arzobispal de Arequipa, Archivo Regional de Arequipa, Archivo Municipal de Arequipa,

- Fuente material; Museos de la región, música, pinturas, poemas, habla popular loncco.

- recolección de datos: la ficha documental

- procesamiento de datos, análisis mediante software de ciencias sociales

\subsection{Técnicas e instrumentos de investigación cualitativa}

\begin{tabular}{ccc}
\hline Método cualitativo & técnica & instrumentos \\
\hline etnográfico & Trabajo de campo & Registro etnográfico \\
\hline Histórico & heurística & Ficha documental \\
\hline Observación participante & Trabajo de campo & registro \\
\hline Entrevista a profundidad & Trabajo de campo & Cedula de entrevista \\
\hline Estudio de casos & Trabajo de campo & registro \\
\hline Análisis del discurso & argumentación & Ficha documental \\
\hline
\end{tabular}

\section{Resultados}

\subsection{Historia de la tradicional entrada de ccapo}

Existe la comprensión por la cual se considera la entrada de ccapo como la extracción de este vegetal, cargar en burros y llevar a la plaza principal del pueblo en día de víspera de la fiesta patronal y quemar este arbusto para calentar las noches frígidas de nuestra región ${ }^{11}$; esta mirada es muy limitada de lo que verdaderamente es la entrada de ccapo y yareta; para aseverar nuestro afirmación nos basaremos en los estudios de historiadores, sociólogos, documentación de fuentes de archivo e impresas.

En una nota, Zamacola y Jauregui pide al Intendente Álvarez y Jiménez en 1789 adscriba los apus Chachani y Charcani a los pueblos de Cayma y Yanahuara

Providencias que juzgase más oportunas a efectos de que, haciendo comparecer ante sí a los caciques de Yanahuara y Cayma, se decida la duda de a cuál de los dos pueblos pertenecen los cerros vulgarmente llamados Chachani y Charcani. En estos cerros, aunque a la vista tan áridos, estoy informado habita bastante gente con título de leñateros, caperos, carboneros y otros pastores de cabras y vacas, (Zamácola y Jáuregui 1958, 77)

Flora Tristán en 1833 sobre las fiestas patronales y la entrada de ccapo señala:

"a la cabeza de la procesión marchaban las bandas de músicos y de bailarines, todos disfrazados. Algunos negros y zambos, se alquilaba por un real al día o para representar un rol en esta farsa religiosa ,la iglesia los disfraza con

\footnotetext{
${ }^{11}$ Existe en las fiestas patronales de la costa norte, sierra central como Pamparque, Utec, Chipao y parte de la selva; la costumbre de realizar la chamizada, en el caso de Huamanga en la fiesta de Cuasimodo; el UMA, es encargado de traer el chamiso. En cambio en Arequipa la entrada de ccapo tiene otra connotación, es en si misma la fiesta de víspera la cual esta compuesta por el encuentro o tirapay donde las autoridades religiosas reciben a la comunidad o pueblo mediante la apaccata que le hace el visitante, la cual esta constituido con hojas de coca, chicha, quienes liban y hacen una tinka a los apus; luego sigue un pago a la tierra con el maestro de la zona que fue pegado por un rayo y debe tener labio leporino, además continua con la presentación de lo mejor que tiene la comunidad o pueblo es el caso de los productos que cosecharon o extrajeron, continua las danzas típicas, que termina en un pasacalle. Además de Cayma y Socabaya que siempre realizan su entrada de ccapo tenemos a San Juan de Tarucani, Chiguata, Santiago de Chuca.
} 
las vestimentas más burlescas ; los viste de Pierrots, de arlequines, de tontos o de otros caracteres del mismo género y les da para cubrirse la cara, malas máscaras de todo los colores, los cuarenta o cincuenta bailarines hacían gestos y contorsiones de una cínica imprudencia, molestaban a las negras y a las muchachas de color formadas en fila, les dirigían toda clase de frases obscenas. Estas mezclándose en la broma, intentaban por un lado reconocer a las máscaras..., después de los bailarines aparecía la virgen vestida con magnificencia, después seguía el obispo con su clero. Enseguida venían los religiosos de los conventos...las autoridades terminaban la fila oficial, en seguida..., por la masa del pueblo (Tristán, 1986, p. 90).

Este dato es por demás esclarecedor en torno a la festividad de la virgen de las Mercedes en los recuerdos de Tristán por 1833, ya define de manera ancestral a los hoy mojigangos y la procesión tiene elementos que recuerdan a las formas de la entrada de ccapo.

En otro documento se ha encontrado que los Devotos de la Sma. Virgen de los Dolores, en 1922 solicitan el ccapo a la comuna caimeña para mantener la antiquísima tradición de la entrada de ccapo:

...que se veneran en nuestra iglesia, haga el día de su fiesta, la entrada de llamada Ccapo, y que consiste e que los devotos se surten, se halla situado en los términos del municipio de su digna presidencia suplico, se sirve ratificar la concesión de que ha gozados costumbre inmemorial, concediéndola por escrito a perpetuidad, a fin de evitar dudas y molestias ulteriores, Creo que en ello, señor alcalde, hará U. una labor efectiva y de utilidad pública, en bien de la humanidad desvalida y menesterosa, por lo que quedaremos eternamente reconocidos ${ }^{12}$.

El F. Buenaventura Reayo en 1922 también solicita como guardián de la Recoleta se le dé la concesión con los fines de la festividad de la virgen de los Dolores, la municipalidad de Caima resuelve la cesión a perpetuidad:

A 15 de marzo de 1922, Visto en sesión de la fecha la solicitud que procede del guardián del Convento de la Recoleta de esta ciudad...Se resuelve, ratificar dicha concesión, para que el Convento de la Recoleta, por intermedio de los devotos de la Sma. Virgen de los Dolores de Iglesia puedan con la mayor libertad extraer el "capo" de los montes de propiedad de este Concejo en la cantidad que necesitan para los fines altamente humanitarios a que se refiere su solicitud; sin que por tal extracción se les cobre ningún centavo de derechos, la cual es a perpetuidad y solo en el día de la St. Virgen de los Dolores, tal como lo piden; debiendo expedirse propia certificada de esta resolución para que les sirve de título al convento referido ${ }^{13}$.

Según Héctor Ballón Lozada, la entrada de ccapo es una costumbre que viene de la colonia, y que tiene como practica todo un conjunto de actividades y rituales que las describe prolijamente.
La entrada de ccapo, otra costumbre ancestral respetada y conservada desde la colonia la misma que se realiza un día antes de la fiesta central. Previamente el devoto acompañado por vecinos y amigos, viajan a la parte alta de Arequipa, como Cabrerías...esta tarea era cumplida con un mes de anticipación, trayendo el material en burros, mulas y llamas que eran puesta a secar para la gran fiesta ....los devotos vestidos tradicionalmente cargaban los burros con el ccapo y yareta sobre ellos colocaban banderas y campanas (Ballon 2007, 124).

Además de cencerros que producían un sonido nítido, anunciaba la entrada de ccapo; este instrumento mas allá de la sola campanilla para su sonido acústico, además tenían piezas de huesos que eran sacados del cementerio de Cayma en el escarbo de huesos y colocados en lo cencerros como forma de ritual a los seres queridos que habían fallecido ${ }^{14}$.

Esta entrada consistía en el ingreso de diversas actividades, entre las que se pueden citar, el acompañamiento de la banda de los caperos, troya que iba desde la Tomilla hasta la Acequia alta en la zona de tampisenca, los castillos, la quema del ccapo y la yareta, la diana y el ponche, las vianderas, las danzas y los productos de la tierra; desde allí los devotos se trasladan a su domicilio, donde la fiesta continua hasta el amanecer y sobre todo se nota la comunión de todos los pobladores quienes comparten la fe y una buena amistad, y no permiten que a pesar del tiempo se pierda esta tradición tan peculiar y especial (Ballon 2007, 125).

A su vez el maestro Félix Rosado Gallegos en su pletórico "Cayma Historia Tradición y cultura", señala que

La entrada de ccapo es una estampa costumbrista única y propia de los pueblos tradicionales de Arequipa, es la que preside la fiesta de los santos patronales de los pueblos ancestrales, a la de aniversario de Arequipa se suma lo que más distingue a esos viejos pueblos, (la entrada de ccapo) esta engalanado los "cuetes", el carnaval, los conejos "chactados" la chicha, el prende y apaga y las danzas folclóricas populares. Los burros cargados de ccapo, con banderitas peruanas y cencerros musicales van por las calles derrochando vivencias propias de Arequipa trabajadoras de la municipalidad, vestidas a la usanza de las labradoras, regalan el donaire de la mujer arequipeña, invita al pueblo, mote Chicha y anís Najar, el carnaval de Acequia Alta es el que despierta la alegría ....El conjunto de cuerdas tradición de acequia Alta, no cesa de cantar:

Acequia Hermosa

Tierra de valientes y

De lindas mujeres.

La banda de ccaperos del maestro Coaquira Chilla, con el carnaval Arequipeño y con la Benita del recordado compositor Benigno Ballón Farfan..la banda y las danzas folclóricas de los centros educativos dan mas alegría y colorido a la entrada de ccapo....el carro alegórico del pueblo tradicional de la

\footnotetext{
${ }^{12}$ ADC-Arequipa, libro N. ${ }^{\circ} 78$, año 1922-1928, fol. 402. Solicitud de concesión de extracción de ccapo por parte de Fr. Buenaventura Reayo, guardián de convento de la Recoleta. 15 de marzo de 1922.

${ }^{13}$ ADC-Arequipa, libro N. ${ }^{\circ} 78$, año 1922-1928, fol. 402. Ratificación municipal para que el Convento de la Recoleta estraiga "capo" para la celebración de entrada de Sma. Virgen de los Dolores.

${ }^{14}$ Entrevista concedida por el señor Hermenegildo Zevallos, de 70 años, profesión abogado; poblador de la Tomilla.
} 
Acequia Alta, es una síntesis de las tradiciones de nuestras tierra: lacayotes , conejo chactados, huatía, chicha, el infaltable carnaval...el remate es de rompe y raja, el prende y apaga, una copita de anís najar prende el fuego, y luego tomamos la chicha y lo apagó...Sobre la champa la piedra es la voz del pueblo.pueblo tradicional de la Acequia Alta, es una síntesis de las tradiciones de nuestras tierra: lacayotes , conejo chactados, huatía, chicha, el infaltable carnaval... el remate es de rompe y raja, el prende y apaga, una copita de anís najar prende el fuego, y luego tomamos la chicha y lo apagó...Sobre la champa la piedra es la voz del pueblo.

Los que se quedaron en Chapi Chico. ${ }^{15}$ Con este enjundioso título en la década de los treinta anotician:

No todos los devotos de la virgen de Chapi pudieron ir a Chapi autentico. Se quedaron en Chapi Chico ... En la víspera llegaron siete, ocho diez cargas de capo desde las faldas del Chachani y las juntaron, ya no para el sacrificio, sino para el incendio. Un rascacielos de fuego broto del capo, Una "entrada" de 20 pisos, en honor a "la mamita"... SOPLEN!

Los caperos soplaron a toda hora las marchas y bailes populares. A ella se le juntaron los que cuentan notas en zampoñas. "Soplen, caperos!". Y los caperos soplaron, dóciles, animosos felices de musicalizar la profesión, q' todavía no ha recurrido a discos de victrola para desplazarlos... Cantaban a la música de los caperos. Hacía de batuta un bastón que llevaba el viejo camayo de la chacra más grande.... Los caperos soplaron como nunca, porque apagaban el frio de los compadres que se invadían terreno en el baile. "No hay primera sin segunda!". El frio emponchado como labriego jaranero escapaba con la marinera.

Incluso cuando invita la Municipalidad Provincial a todos los distritos a la realización de la entrada de ccapo por las fiesta jubilares de Arequipa, el argumento de dicha petición es elocuente

Con ocasión de celebrar el 441 aniversario de la fundación españolad de Arequipa, esta abocado en resaltar los valores culturales y artísticos a nuestra ciudad, es con este motivo, recurrimos a su despacho a fin de pedir la colaboración en el programa de fiestas y siendo, la entrada de ccapo una tradición auténticamente Arequipeña ${ }^{16}$ pedimos a su concejo que dignamente dirige, sirva presentarnos una estampa folclórica para el día 14 de agosto a horas $5 \mathrm{pm}$ en la plaza España de nuestra ciudad, la como se realiza en vuestro pintoresco distrito con banda de ccaperos que ofrezca una retreta durante la quema de ccapo $^{17}$

Entonces se aclara que la entrada de ccapo es un legado antiquísimo que está vinculado con costumbres prehispánicas dentro de la cosmovisión como es el fuego, el agua; además tiene que ver con la vida cotidiana y las fiesta patronales; donde se involucran los desastres, el comercio, el arriero y los caminos; producto de esta conjugación de factores se da una redefinición y que contiene todos los aspectos de las tradiciones, costumbres y vida del arequipeño la cual la representan en la entrada de ccapo caymeño.

\subsection{La virgen de la Candelaria de Cayma: La entrada de capo}

La denominación de Candelaria es porque se bendicen cirios, la encienden y arden, es decir deviene de candela, el fuego como elemento purificador, además se les denomina a inicios de la colonia como la linda o de la purificación.

El evangelizador de la Chimba fue Fray Antonio de Ulloa y es en ese tenaz esfuerzo de conversión de los indígenas, es que las imágenes occidentales hacen presencia en Arequipa y Cayma siendo la Virgen de Candelaria la más importante cuyas honras la podemos seguir mediante la fuente más antigua que menciona Evaristo San Cristóbal quien refiere que en 1544 se construyó una ermita muy precaria y el lugar era visitado por los españoles, es presumible que fuera la virgen de la candelaria o la purificación, después esta imagen estuvo depositado en la zona de Lari Lari hoy cementerio de Cayma(Evaristo San Cristóbal, 1949, p. 3)

Según esta fuente se acostumbra en la víspera de la candelaria realizar la entrada de ccapo, pero es necesario detenernos a comprender en si la esencia de esta actividad religiosa: primero se elegía un mayordomo de la fiesta y este hacía que se devotara y asumiera, el encargo y otro devoto la entrada de ccapo, la cual tenía como característica primero el ritual del pago a la tierra en la zona del cual se iba extraer la Yareta y el ccapo, este pago a la pachamama tenía en algunos la forma de la tinka con aguardiente y coca en la zona de extracción que eran las faldas del Chachani después el traslado en llamas y burros del ccapo y la yareta desde la zona de Cabrerías desplazándose con mayor población hasta la plaza principal de Cayma donde se realiza el Tirapay o encuentro entre el mayordomo y devotos que ofrendan a la Candelaria; y el párroco, quien sale al encuentro a recibirlos dándose un momento de mucho simbolismo mágico religioso básicamente es el encuentro entre la cultura ancestral que desde su formas entrega su cargamento a la virgen -mundo andino- y el párroco en representación de la divinidad acepta esta entrega o Apaccata con elementos occidentales, representado en libar el vino; y los elementos andinos como el chacchar la coca y la Chicha con la comitiva, habiendo realizado un sinnúmero de actos como ofrendar a la virgen y a la Pachamama, donde se pide los mejores parabienes a los participantes, de igual forma el alcalde varas lo hace para que la patrona los llene de beneficios en ese año; todo acompañados de su banda ccaperos; sus burros enjaezados, con su cargamento de ccapo y yareta, además la comitiva está conformada por danzas y los productos de la tierra.

En un informe de 1975, el arzobispo de Arequipa Monseñor Leonardo Rodríguez Ballón señalaba que los santuarios de renombre nacional eran de Cayma y Chapi que en términos de culto reviste ha seguido como la misma forma de organización de la fiesta, pero con mayor unción y derroche económico. A todos los títulos ganados han agregado también el sentido de patriotismo, como la de

\footnotetext{
${ }^{15}$ Diario El Sur, 1935, Mayo 3p. 5.

${ }^{16}$ Las cursivas y negrita es nuestra

${ }^{17}$ Archivo Documental de Cayma, 19801981 T. 8
} 


\section{VÉRITAS Vol. 20 N¹ (2019) 7-21}

Cayma que fue llamada en 1825 libertadora.

Entonces como entender la entrada de ccapo caymeño, el culto a la virgen de la Candelaria y la cosmovisión del fuego; debemos reconocer que los asentamientos de la chimba estuvieron fuertemente impactados por los Collaguas y grupos altiplánicos, es en esa medida que la cosmovisión aymara, prevalece como Acapacha, está dividida en tres sectores que tienen sentido vertical, cada uno de los cuales tiene un referente geográfico; el primer nivel o sector está relacionado a las cumbres de mayor elevación, nevados y volcanes, a cuyos espíritus, Apus, se orientaban ritos propiciatorios que incluían sacrificios de llamas y humanos. A los apus Chachani, Misti y Pichi Píchu, les consideraba como proveedores del agua y como fuente de toda vida, eran invocados en crisis y desastres. El segundo nivel: el culto anual coincidía con el día de los compadres que es en febrero y el otro aspecto es que la virgen esta vinculada a la Pachamama; imagen cristiana el equivalente de la fecundidad prehispánica otorgada a la tierra valorada en el sustento en la abundancia de agua y pastos que celebran en los meses de enero y febrero, época de las fiestas centrales de la Virgen de la Candelaria. El tercer nivel supone los valles, ríos y acueductos, personificados en la figura de la serpiente o "Amaru" y cuyo culto se efectuaba en el inició de los ciclos agrícolas de Arequipa; la cuenca del Chili es recurrente, además el canal de Zamacola desviado por el canal la Chulla que irriga todas las tierras de Cayma, Yanahuara, el Cural, etc. La cual tiene una antigüedad prehispánica; los desvíos en las alturas de Imata en el hito de Vincocaya se hizo hace 100 años; cuyo canal existe en la actualidad. Todo ello al pie de los volcanes "apus" Misti, Chachani y Pichu Pichu, temidos y venerados por su capacidad de producir sismos entre congéneres aymaras y Collaguas (Mota 1985, 133)

Las Candelarias del puente religioso Cayma-CharacatoChapi fueron incorporando a su contenido ritual esta cosmovisión prehispánica en la medida que progresaba la cristianización, desplegada por los misioneros. Su evolución responde a la misma necesidad de falta de agua para una agricultura que depende enteramente del riego (caso de Cayma y Characato y toda la campiña) o de las lluvias en las zonas altas; en pocos lugares la Candelaria era tan requerida por agricultores que cuando existe una inminente amenaza de sequía no dudan de llevarla en procesión hasta el "Ojo de Agua", "Agua del Milagro". En Cayma continúan siendo los agricultores los mayores gestores de su fiesta. (Mota 1985).

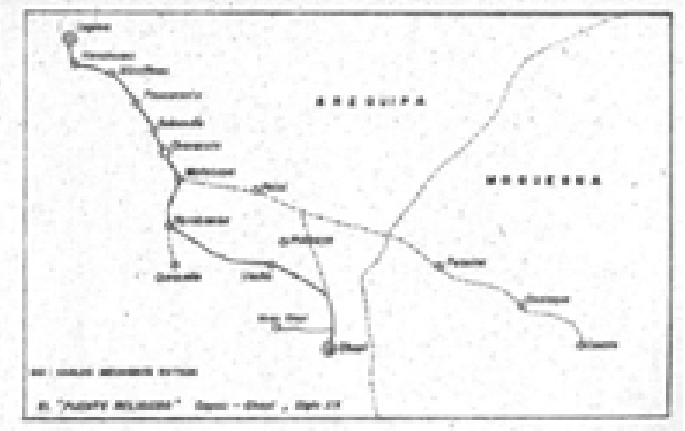

\subsection{Fiestas tradicionales y su valor identitario}

Es necesario aclarar que todas las fiestas patronales religiosas contaban con la entrada de ccapo y estas llenaban el calendario anual con sus festejos mas no así las fiestas cívicas generadas por el día de la creación o fundación de la ciudad, pero que tenían siempre la advocación de un santo o una virgen.

Empezaremos con la finalización de la fiesta ya que es en ese momento donde se devotan el mayordomo y los devotos: está a punto de terminar la fiesta patronal, después de la procesión donde el santo patrón o cruz se ha de guardar, el sacerdote invoca a los feligreses para que asuman el cargo como mayordomos y devotos para el próximo año, generalmente por tradición de familia, asumen el cargo por tres años consecutivos otros han realizado la promesa de hacerlo, como el caso del Sr. Salomón Vargas Muñoz cada diez años ${ }^{18}$, pero se ha encontrado casos en que el registro ya está dado para por lo menos los últimos cinco años, una vez repartidos los cargos del próximo año, se ensalza con una salva, repique de campanas y se remata con la Banda de ccaperos.

Dos semanas antes de la celebración se realiza "el convite" saliendo el mayordomo con el Guion (estandarte, o priorato) con devotos y familiares. Luego de hacer un recorrido por las principales arterias llegan al atrio de la iglesia donde en piadosa sumisión se arrodillan dirigiendo alabanzas al santo, después de la bendición del párroco, la multitud se aproximan a la casa del mayordomo o devoto de "convite" donde se inicia ya el festejo; es interesante lo que indica Carpio Muñoz:

El viernes anterior al domingo de fiesta se reúnen en casa del "devoto de Ccapo" quienes lo acompañaran, con sus acémilas, su traje y equipos de faena y sus "atados" de frazadas y refrigerios. El devoto le invita el almuerzo, casi siempre un chupe y un segundo "con copete" y chicha a discreción. Parten después del medio día...casi siempre prefieren al Chachani porque tiene unas faldas menos agrestes. Al morir de la tarde llegan a las estribaciones donde crece el Ccapo, acampan en seguida el devoto paga a las montañas para sacar el ccapo; simultáneamente piccha coca, retiene un trago de pisco o cañazo en la boca y fuma un cigarrillo, luego arroja el humo y escupe el líquido y la coca mirando las montañas y siempre sentado sobre sus piernas cruzadas. Lanza una oración en quechua y castellano, enseguida abre con sus manos un hueco en la tierra, en la montaña y entierra la botellita de la que sorbio, hojas de coca y cigarrillo...y sintiéndose con permiso de la montaña comienza a sacar... el Ccapo...el sábado llegan los devotos de ccapo, adornan las cargas con banderitas peruanas y esperan .... a las tres de la tarde el mayordomo portando el guion acompañado de su esposa e hijos y banda de músicos se dirige hacia la casa de la entrada de ceras....mujeres en la calle tiene cirios en las manos...el mayordomo después de varios brindis invita a iniciar la entrada, con ...reventazón de una troya. (Carpio, 2017)

El orden de la comitiva es la siguiente primero el mayordomo con el guion, acompañado del devoto de ceras; luego la banda de ccaperos, después las señoras con sus ceras

${ }^{18}$ Entrevista realizada al mayordomo 2012, Salomón Vargas Muñoz, de la fiesta de la Santísima Cruz de La Tomilla. 
encendidas y más atrás los burros con el ccapo. Se entra a la iglesia se recibe la misa, luego se retiran a la casa del devoto de la entrada donde hay un convite y es el inicio de la fiesta inaugurado por el mayordomo, los devotos y sus esposas, se enciende el Ccapo a las $8 \mathrm{pm}$ y se inicia la quema de castillos. Se abre la algarabía.

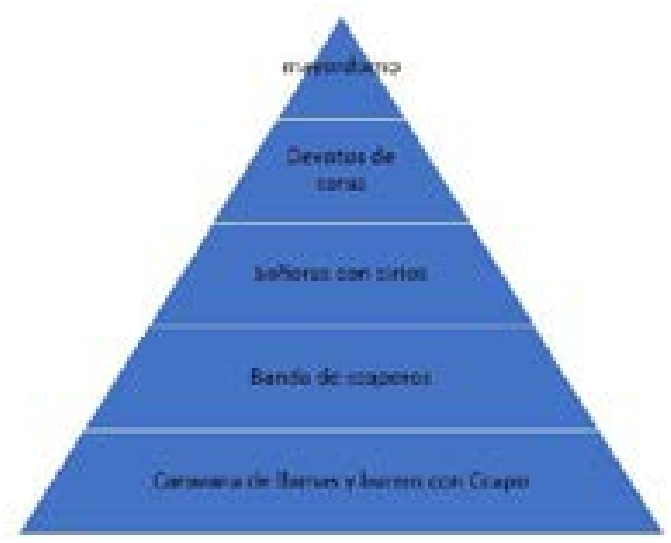

Fig. 10: Pirámide categorización de los cargos y su participación. Fuente: Zapata D., M. (2012). Historia, identidad y representación: Entrada de Ccapo en Cayma

\subsubsection{Identidad y representación: la entrada de ccapo en Cayma}

Se observa que dentro de la distribución de la procesión para la víspera de la fiesta patronal de mantiene este orden: Mayordomo, por ser el personaje organizador de la festividad, con sus invitados que generalmente son sus parientes cercanos y amigos; los devotos dirigidos por el devoto de ceras, continúan la señoras con cirios, luego banda de Ccaperos y finalmente caravana de llamas y burros, pero en la actualidad se estila que antes de la banda de caperos exista una o más agrupaciones de danza como se observó en la entrada a la Tomilla en su víspera de la Santísima Cruz del $2012^{19}$

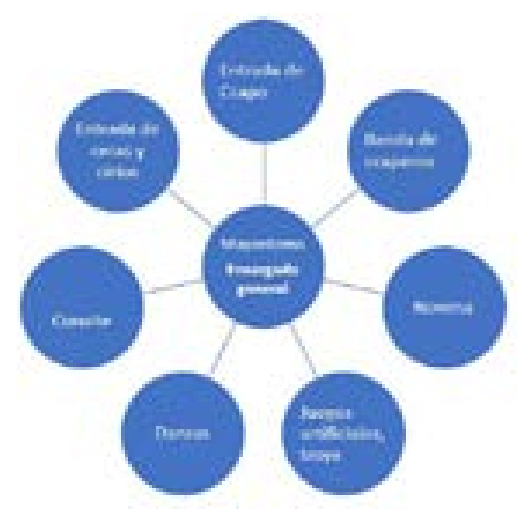

Fig. 11: Diagrama cargos importantes en la entrada de ccap. Fuente: Zapata D., M. ( 2012) Historia, identidad y representación: Entrada de Ccapo en Cayma.

\section{CONCLUSIONES}

1. La entrada de ccapo es una práctica de usos y costumbres basados en la tradición arequipeña que tuvo sus orígenes en el prehispánicos y europeo: prehispánicos bajo la acción votiva definida por el fuego y los desastres que el ccapo visibiliza el culto al fuego en el ande, y desde el punto de vista occidental se orienta a un simbiosis entre esta sustancia y los santos patronos que fueron traídos inicialmente ante tanto desastres, asumen el marco de protección de la ciudad y que forman el panteón sacro.

2. Existe una fuerte presencia de las candelarias milagrosas, en la visión del campesino que representa la Pachamama; son este conjunto de elementos reunidos ante el ccapo, representan una forma de comunión entre la colonia y el prehispánico.

3. Otro elemento que origina la entrada de ccapo son los caminos arrieros e intercambios que definen formas de vaso intercomunicantes entre el trajín de las rutas que realizan y por ende son trasmisores de cultura y sobretodo un dialogo permanente entre los chacareros y punarunas.

4. La entrada de ccapo en la actualidad es una fiesta que se practica como advocación al día central de Arequipa la cual está definida por el abigarramiento de tradiciones que se dan en Arequipa cada estampa en esta entrada trasunta la historia cultural de esta región, con personajes y características muy particulares.

5. Es importante entender existe, a partir de formas de hibridación, un impulso de algunos distritos sobre esta práctica, pero también en las zonas altoandinas se ha perennizado esta práctica, con peculiaridades muy propias como taripay o bienvenida de los gobernadores a las diferentes comunidades campesinas que en el aniversario del pueblo viene a felicitar, todo desde la perspectiva de la naturaleza y los frutos que esta presta.

\section{REFERENCIAS BIBLIOGRÁFICAS}

1. Benavente, C. (2010). Arrieraje y el comercio de Arequipa . Historia Menuda. bolsa, L. (10 de mayo de 1881). pelea de toros. La Bolsa, pág. 1.

2. Carpio, J. (1 de mayo de 2017). Arequipa tradicional. Obtenido de la virgen maria en Arequipa: https:// arequipatradicional2.blogspot.com/2017/05/la-virgende-arequipa.html

3. Cespedes, M. (2010). las peleas de toros en Arequipa. Arequipa: Inedito.

4. Echevarría, F. (1952). Memoria de la Santa Iglesia de Arequipa. . Arequipa: Portugal.

5. Escalante, C., \& Valderrama, R. (1983). llameros, troperos y arrieros en Huancavelica. allpanchis vol XVIII, $n^{\circ} 21,65-88$.

6. Glave, M. ( 1989). Trajinantes: caminos indígenas en la sociedad colonial, siglos XVI-XVII. Lima: Instituto de Apoyo Agrario.

7. Hocqengahem, M. (2016). Los caminos rurales de herradura. Obtenido de https://es.scribd.com/ document/307445642/Caminos-de-Herradura 
8. Khazanov, A. (1984). Nomads and the outside world. Madison: Library of Congress Cataloging-inPublication Data .

9. Lavalle, B. (2011). Miedos terrenales, angustias escatológicas y pánicos en tiempos de terremotos en el Perú a comienzos del siglo XVII. . España: E-Spania.

10. Leon, C. d. (2005). cronica del Perú el señorio de los incas. Lima : Ayacucho.

11. Medinacelli, X. (2010). Sariri; los llameros y la construcción de la sociedad colonial. La Paz: IFEA, Plural editores, ASDI. IEB.

12. Motta. (1985). El Agua, la Serpiente y la Candelaria de Arequipa. . Lima: Universidad Nacional Mayor de San Marcos.

13. Murúa, M. d. (2001). Historia General del perú. España: Manuel Ballesteros Gaibrois.

14. Núñez, L., \& Briones., L. (2017). tráfico e interacción entre el oasis de pica y la costa arreica en el desierto tarapaqueño (Norte De Chile). Estudios Atacameños, No 56, pp. 133-161.

15. Sica, G. (2010). Del tráfico caravanero a la arriería colonial indígena: En Jujuy. Siglos XVII y XVIII: Revista Transporte y Territorio $\mathrm{N}^{\mathrm{o}} 3$, Universidad de Buenos Aires . Revista Transporte y Territorio ISSN 1852-7175 www.rtt.filo.uba.ar, 22-39.

16. Simiand, F. (2003). Metodo historico. Obtenido de https://www.pucsp.br/cehal/downloads/relatorios/ revista_empiria_artigos_biblioteca_uned/eserv_ empiria_metodos_historico_c_sociais.pdf

17. Taype, G. (03 de 2005). Gazeta de Antropología,artículo $06 \cdot$. Obtenido de http://hdl.handle.net/10481/7179

18. Tomoeda, H. (1977). La llama es mi chacra, Mitos y canciones ceremoniales en comunidades de Puna. En J. A. Ochoa, pastores de puna. Lima: IEP.

19. Zapata D., M. ( 2012). Historia, identidad y representación: Entrada de Ccapo en Cayma. Arequipa.

20. Zegarra M, G. (1973). Arequipa,en el Paso de la Colonia a la Republica visita de Bolivar . Arequipa: Cuzzi y Cía S.A 2da ed.). : . 